\title{
Piotr Bielarczyk
}

Uniwersytet Warszawski

\section{SKUTKI OPRÓŻNIENIA URZĘDU PREZYDENTA W POLSKICH KONSTYTUCJACH XX WIEKU}

Akademickie kryteria podziału norm prawnych na m.in. indywidualne i generalne, abstrakcyjne i konkretne czy sankcjonowane i sankcjonujące, można uzupełnić o jeszcze jedno: na takie normy, co do których prawodawca zakłada, że będą stosowane, choćby rzadko, i takie, które tworzone są na wypadek sytuacji wyjątkowych, jednostkowych, można rzecz - nadzwyczajnych, z intencją, a wręcz nadzieją, że nigdy nie okażą się potrzebne. Właśnie do tej drugiej grupy norm można zaliczyć przepisy o skutkach opróżnienia urzędu Prezydenta.

Artykuł składa się z dwóch części. W pierwszej kolejności omówiono przepisy kolejnych polskich dwudziestowiecznych konstytucji, odnoszące się do opróżnienia urzędu Prezydenta. Następnie porównano te przepisy z obecnymi przepisami, tj. Konstytucją RP z 1997 roku.

Co do źródeł, z racji podjętego tematu artykuł opiera się przede wszystkim na tekstach aktów prawnych. Dodatkowo wykorzystano komentarze do poszczególnych konstytucji i opracowania, w szczególności komentarze Augusta Paszkudzkiego do Konstytucji Marcowej, Ireny Posseltówny, Tadeusza Orlewicza i Konstantego Grzybowskiego do Konstytucji kwietniowej oraz komentarze do obecnej Konstytucji z 1997 roku. 


\section{Konstytucja Marcowa z 1921 RoKU}

Zgodnie z art. 40 Konstytucji Rzeczypospolitej Polskiej z 17 marca 1921 („Konstytucji Marcowej”), jeżeli Prezydent nie mógł sprawować urzędu, oraz w razie opróżnienia urzędu Prezydenta wskutek śmierci, zrzeczenia się lub innej przyczyny, zastępował go Marszałek Sejmu. Następnie, zgodnie z art. 41, Marszałek Sejmu zwoływał Sejm i Senat, które tworzyły wspólnie Zgromadzenie Narodowe celem wyboru Prezydenta, pod przewodnictwem Marszałka Sejmu. Gdyby Sejm był rozwiązany w chwili, gdy urząd Prezydenta jest opróżniony, to Marszałek Sejmu miał niezwłocznie zarządzić nowe wybory do Sejmu i Senatu. Sytuacja szczególna została wskazana w art. 42, zgodnie z którym jeżeli Prezydent przez 3 miesiące nie sprawowałby urzędu, Marszałek miał niezwłocznie zwołać Sejm i poddać jego uchwale, czy urząd Prezydenta należy uznać za opróżniony.

A zatem jako przyczyny opróżnienia urzędu wskazano śmierć, zrzeczenie się urzędu lub ,inne przyczyny” - ta ostatnia kategoria, bardzo ogólna, miała być zdaniem Augusta Paszkudzkiego rozumiana jako sytuacja, w której Prezydent przez 3 miesiące nie sprawuje urzędu lub, gdy zostanie pozbawiony urzędu wyrokiem Trybunału Stanu, w razie zdrady kraju, naruszenia Konstytucji z winy umyślnej lub popełnienia przestępstwa $z$ ustaw karnych, choćby przestępstwo takie nie pozostawało $\mathrm{w}$ związku z pełnionym urzędem ${ }^{1}$.

Co ważne, Konstytucja Marcowa rozróżniała sytuację opróżnienia urzędu i niemożności sprawowania urzędu przez Prezydenta. Choć wprost tego nie wskazano, niemożność sprawowania urzędu miała być rozumiana jako przejściowa - np. w wypadku opisanym w art. 51 Konstytucji, tj. w razie postawienia Prezydenta w stan oskarżenia przed Trybunałem Stanu. Zapewne także przyczyny zdrowotne uzasadniałyby przyjęcie niemożności czasowego wykonywania urzędu Prezydenta. Jak wspomniano, gdy stan niemożności sprawowania urzędu utrzymywał się co najmniej 3 miesiące, Marszałek Sejmu miał

\footnotetext{
${ }^{1}$ A. Paszkudzki, Konstytucja Rzeczypospolitej Polskiej z dnia 17 marca 1921 z uwzględnieniem zmian ustalonych ustawa z dnia 2 sierpnia 1926. Komentarz, LwówWarszawa 1927, s. 62.
} 
obowiązek niezwłocznie zwrócić się do Sejmu o przegłosowanie, czy urząd Prezydenta należy uznać za opróżniony.

Zwraca uwagę, że jako osoba działająca, bo nie zastępująca Prezydenta, został wskazany Marszałek Sejmu. Co istotne, Konstytucja Marcowa nie przewidywała wprost, aby Marszałek Sejmu, bądź jakakolwiek inna osoba, wykonywała obowiązki Prezydenta do czasu wyboru nowego Prezydenta - wskazała jedynie, że zadaniem Marszałka Sejmu było doprowadzenie do wyłonienia następnego Prezydenta, ewentualnie poddanie pod głosowanie, czy urząd Prezydenta należy uznać za opróżniony. Nie może jednak budzić wątpliwości, że intencją ustawodawcy konstytucyjnego było umożliwienie Marszałkowi Sejmu zastępowania Prezydenta we wszystkich obowiązkach - w przeciwnym razie przepis mówiący o zastępowaniu Prezydenta, niemogącego sprawować urzędu (w domyśle: czasowo) przez Marszałka Sejmu, pozbawiony byłby sensu. Nadto nie sposób przyjać, że ustawodawca dopuszczał stan, w którym przez trzy miesiące nikt nie będzie wykonywał obowiązków Prezydenta.

Przepisy Konstytucji Marcowej o skutkach opróżnienia urzędu Prezydenta zostały zastosowane dwukrotnie - pierwszy raz po śmierci Prezydenta Narutowicza, między 16 a 22 grudnia 1922, drugi raz po ustąpieniu Prezydenta Wojciechowskiego, między 14 maja a 4 czerwca 1926. W obu wypadkach obowiązki Prezydenta wykonywała ta sama osoba - Marszałek Sejmu Maciej Rataj.

\section{Nowela SierpNiowa z 1926 ROKU}

Ustawa z 2 sierpnia 1926, zmieniająca i uzupełniająca Konstytucję Rzeczypospolitej z 17 marca 1921 („Nowela Sierpniowa”) nie wprowadziła zmian w przepisy dotyczące skutków opróżnienia urzędu Prezydenta.

\section{Konstytudua Kwietniowa z 1935 ROKU}

Istotne zmiany miały natomiast miejsce w Konstytucji Rzeczypospolitej Polskiej z 23 kwietnia 1935 („Konstytucji Kwietniowej”)².

${ }^{2}$ Poniższe rozważania opierają się na następujących komentarzach do Konstytucji Kwietniowej: K. GrzYBowsKi, Zasady Konstytucji Kwietniowej. Komentarz prawniczy 
Zgodnie z art. 21, jeżeli przed upływem 7-letniego okresu urzędowania nastapi zgon Prezydenta albo Prezydent zrzeknie się urzędu - Marszałek Senatu zwoła niezwłocznie Zgromadzenie Elektorów celem wskazania przez nie kandydata na Prezydenta, a w razie wskazania ze swej strony innego kandydata zarządzi głosowanie powszechne. W myśl art. 22, jeżeli Prezydent nie może trwale sprawować urzędu, Marszałek Senatu zwoła połączone Izby Ustawodawcze celem rozstrzygnięcia, czy Urząd Prezydenta należy uznać za opróżniony. Uchwała uznająca urząd za opróżniony, zapada większością 3/5 ustawowej liczby członków Izb Połączonych. W wypadku powzięcia takiej uchwały, Marszałek Senatu zwoła niezwłocznie Zgromadzenie Elektorów.

Istotny był przepis art. 23 Konstytucji, zgodnie z którym w czasie, gdy urząd Prezydenta jest opróżniony, funkcje Prezydenta sprawuje zastępczo Marszałek Senatu, a gdyby Senat był rozwiązany - Marszałek rozwiązanego Senatu; korzysta on wówczas ze wszystkich uprawnień $\mathrm{z}$ urzędem Prezydenta związanych.

Wreszcie przepis art. 24 wprowadzał zasadę, która po czterech latach, w okresie II Wojny Światowej miała zapewnić ciagłość władzy państwowej - w razie wojny okres urzędowania Prezydenta miał zostać przedłużony o trzy miesiące od zawarcia pokoju; Prezydent osobnym aktem miał wyznaczyć wówczas swego następcę na wypadek opróżnienia się urzędu przed zawarciem pokoju.

Zwraca uwagę kilka okoliczności związanych z zacytowanymi przepisami.

Po pierwsze, jako przyczyny opróżnienia urzędu wskazano jedynie trzy sytuacje: śmierć Prezydenta, jego zrzeczenie się urzędu oraz „trwałą niemożność sprawowania urzędu". Odpadła przesłanka pociagnięcia Prezydenta do odpowiedzialności przed Trybunałem Stanu, gdyż

do części I ustawy konstytucyjnej, Kraków 1937; T.J. OrLewICz, Zasady Konstytucji 23 kwietnia 1935 roku. Komentarz oraz petny tekst, Warszawa 1935; I. PosselTównA, Konstytucja polska: z dnia 23 kwietnia 1935 roku wraz z Ustawa Wyborczq do Sejmu, Senatu oraz Ustawa o wyborze Prezydenta Rzeczypospolitej, Warszawa-Lwów 1935. Także: E. Zwierzchowski, Prezydent i rzqd w Konstytucji z 23 kwietnia 1935 roku, «Przegląd Sejmowy» nr 2(67)/2005; W. T. KulEsZA, Ustawa konstytucja z 23 kwietnia 1935 roku, «Przegląd Sejmowy» nr 2(67)/2005. 
Konstytucja Kwietniowa, jak wiadomo, nie przewidywała odpowiedzialności konstytucyjnej Prezydenta. Nie został także powtórzony przepis o tymczasowej niemożności sprawowania urzędu przez okres trzech miesięcy, a także nieostra kategoria „innych przyczyn” opróżnienia urzędu. Dodano natomiast przepisy o zasadach zastapienia Prezydenta w czasie wojny.

Po drugie, osobą zastępującą Prezydenta w czasie pokoju, inaczej niż w Konstytucji Marcowej, gdzie wskazany był Marszałek Sejmu, został Marszałek Senatu. Było to wyrazem ogólnej tendencji w Konstytucji Kwietniowej, aby wzmocnić rolę Senatu, wybieranego nie w wyborach powszechnych, ale w $1 / 3$ przez Prezydenta, a w pozostałym zakresie przez obywateli, jak wskazywała ordynacja wyborcza do Senatu z 1935, mających prawo wybierania ,z tytułu zasługi, wykształcenia lub zaufania".

Cytowane przepisy jedynie raz znalazły zastosowanie. Po wybuchu II wojny światowej, Prezydent Ignacy Mościcki wskazał w trybie art. 24 Konstytucji, jako swojego następcę, najpierw Bolesława Wieniawę-Długoszowskiego, a następnie Władysława Raczkiewicza³

\section{Mala Konstytucja z 1947 rokU}

Ustawa Konstytucyjna o ustroju i zakresie działania najwyższych organów Rzeczypospolitej Polskiej z 19 lutego 1947 („Mała Konstytucja"), wprost nawiązywała do Konstytucji Marcowej (m.in. w art. 1). W rozdziale trzecim „Prezydent”, w art. 13 wskazano, że przepisy Konstytucji Marcowej odnoszące się do urzędu Prezydenta, w tym co do stanu opróżnienia urzędu, stosuje się odpowiednio. Wprowadzono tylko jedną, ale istotną zmianę, związaną z tym, że Mała Konstytucja nie przewidywała Senatu, a w konsekwencji nie mogło być zwołane Zgromadzenie Narodowe. W art. 14 wskazano, że w razie opróżnienia urzędu Prezydenta, to Sejm dokona niezwłocznie wyboru Prezydenta.

\footnotetext{
${ }^{3}$ Więcej na ten temat m.in. Prezydenci Polski, red. A. AjnEnKIEL, Warszawa 1991.
} 
5. Konstytudua PRL z 1952 ROKU

Konstytucja Polskiej Rzeczypospolitej Ludowej z 22 lipca 1952 r. nie przewidywała urzędu Prezydenta.

\section{NOWELA KWIETNIOWA Z 1989 ROKU}

Urząd Prezydenta został przywrócony dopiero Ustawą Konstytucyjną o ustroju i zakresie działania najwyższych organów Rzeczypospolitej Polskiej („Nowelą kwietniową” z 7 kwietnia 1989). Nowelizacja wprowadziła też przepisy dotyczące sytuacji opróżnienia urzędu.

Zgodnie z dodanym do Konstytucji PRL, art. 32e, opróżnienie urzędu Prezydenta (wtedy jeszcze Prezydenta PRL), przed upływem kadencji następowało wskutek: 1) śmierci, 2) zrzeczenia się urzędu, 3) uznania przez Zgromadzenie Narodowe trwałej niezdolności do sprawowania urzędu ze względu na stan zdrowia większością co najmniej 3/5 głosów w obecności co najmniej połowy ogólnej liczby członków Zgromadzenia, oraz złożenia Prezydenta z urzędu orzeczeniem Trybunału Stanu. Zgodnie z art. 32b, Marszałek Sejmu miał obowiązek zwołać Zgromadzenie Narodowe w ciagu miesiąca od dnia opróżnienia urzędu Prezydenta. Dalej wskazano, że w razie gdy urząd Prezydenta jest opróżniony, do czasu objęcia urzędu przez nowego Prezydenta, a także gdy Prezydent tymczasowo nie może sprawować urzędu, zastępuje go Marszałek Sejmu.

Kolejne nowelizacje Konstytucji: z 29 grudnia 1989 r. i 27 września 1990 r. nie przyniosły zmian.

\section{MaŁa Konstytucja z 1992 roKu}

Zmianę w zakresie skutków opróżnienia urzędu Prezydenta przyniosła Ustawa Konstytucyjna o wzajemnych stosunkach między władzą ustawodawczą i wykonawczą Rzeczypospolitej Polskiej oraz o samorządzie terytorialnym („Mała Konstytucja”) z 17 października $1992^{4}$.

${ }^{4}$ Szerzej na ten temat: Komentarz do Konstytucji Rzeczypospolitej Polskiej, red. L. GARLICKI, Warszawa 1995. 
W art. 49 wskazano, że opróżnienie urzędu Prezydenta przed upływem kadencji następuje wskutek: 1) śmierci, 2) zrzeczenia się urzę$\mathrm{du}, 3)$ uznania przez Zgromadzenie Narodowe trwałej niezdolności do sprawowania urzędu ze względu na stan zdrowia uchwałą podjętą większością co najmniej 2/3 głosów, w obecności co najmniej połowy ogólnej liczby członków, wreszcie: 4) złożenia z urzędu orzeczeniem Trybunału Stanu. Jako osobę, która miała zastępować Prezydenta, do czasu objęcia urzędu przez nowego Prezydenta, a także, gdy Prezydent tymczasowo nie może sprawować urzędu, wskazano Marszałka Sejmu, a gdy ten nie może tych funkcji wykonywać - Marszałka Senatu. Wprowadzono też nową zasadę - że osoba zastępująca Prezydenta nie może rozwiązać Sejmu.

Zgodnie z art. 29, w razie opróżnienia urzędu Prezydenta, powszechne wybory Prezydenta miał zarządzić Marszałek Sejmu nie później niż w 14 dniu po opróżnieniu urzędu, wyznaczając datę wyborów przypadającą w ciągu 2 miesięcy od dnia zarządzenia wyborów.

Zwraca uwage, że Mała Konstytucja z 1992 roku zawierała bardzo ogólne sformułowanie - „zastępowanie Prezydenta”. Nie było mowy o wykonywaniu jedynie obowiązków czy innych niezbędnych działań - a zatem zastępca mógł wykonywać w s z e 1 k i e kompetencje Prezydenta, oczywiście z wyjątkiem rozwiązania Sejmu.

\section{Konstytucja z 1997 ROKU}

Konstrukcja przepisów dotyczących okoliczności opróżnienia urzędu Prezydenta i skutków tego faktu, jest w Konstytucji Rzeczypospolitej Polskiej z 2 kwietnia 1997 inna, niż we wcześniejszych ustawach konstytucyjnych ${ }^{5}$.

${ }^{5}$ Poniższe rozważania opierają się na następujących komentarzach do Konstytucji: P. Winczorek, Komentarz do Konstytucji Rzeczypospolitej Polskiej z dnia 2 kwietnia 1997 roku², Warszawa 2008; P. SARnECKI, Komentarz do Konstytucji Rzeczypospolitej Polskiej (Dz.U.97.78.483), [w:] P. SARnECKI, Prezydent Rzeczypospolitej Polskiej. Komentarz do przepisów, Zakamycze 2000; W. SKRZYDŁo, Konstytucja Rzeczypospolitej Polskiej. Komentarz, Zakamycze 2002; Konstytucja Rzeczypospolitej Polskiej. Komentarz, red. L. GARLICKI, Warszawa 1999/2001/2003/2005/2007. Wykorzystano 
Konstytucja nie zawiera przepisu wprost wskazującego w jakich sytuacjach dochodzi do opróżnienia urzędu Prezydenta. O „opróżnieniu urzędu" mówi się jedynie jako o przesłance zarządzenia wcześniejszych wyborów (art. 128 i 129). Z art. 131 ust. 2 mówiącego o zasadach zastępowania Prezydenta, gdy ten nie może trwale sprawować urzędu, wynika jednak, że opróżnienie urzędu występuje w razie: 1) śmierci Prezydenta, 2) zrzeczenia się urzędu przez Prezydenta, 3) stwierdzenia nieważności wyboru Prezydenta lub innych przyczyn nieobjęcia urzędu po wyborze, 4) uznania przez Zgromadzenie Narodowe trwałej niezdolności Prezydenta do sprawowania urzędu ze względu na stan zdrowia, 5) złożenia Prezydenta z urzędu orzeczeniem Trybunału Stanu.

Skutkiem opróżnienia urzędu Prezydenta jest, zgodnie z art. 128 ust. 2, konieczność przeprowadzenia przedterminowych wyborów, które zarządza Marszałek Sejmu. Co do osoby zastępującej Prezydenta w razie opróżnienia urzędu, jest nią właśnie Marszałek Sejmu, zgodnie z art. 131 ust. 2, a gdy Marszałek Sejmu nie może wykonywać obowiązków Prezydenta, obowiązki przejmuje Marszałek Senatu.

Powstaje zasadnicze pytanie o zakres kompetencji osoby tymczasowo zastępującej Prezydenta oraz o czas, w jakim to zastępstwo jest możliwe ${ }^{6}$.

Co do kompetencji, Konstytucja wprost wskazuje w art. 131 ust. 4, że osoba wykonująca obowiązki Prezydenta nie może postanowić o skróceniu kadencji Sejmu. Innych ograniczeń Konstytucja wprost nie przewiduje. Wydaje się jednak, że użycie w art. 131 określenia „wykonywanie o b o w i ą z k ó w Prezydenta" sugeruje, że Marszałek Sejmu może jedynie podejmować takie działania, które wiążą się ze zobowiązaniami Prezydenta, w szczególności opatrzonymi nieprzekraczalnymi terminami, nie zaś z uprawnieniami o charakterze dyspozycyjnym, nie zdeterminowanymi czasowo. Innymi słowy, jak zauważył m.in. Prof. Dariusz Dudek, Marszatek Sejmu nie jest uprawniony do

istotny artykuł D. DudKA, Harce wokót ustawy zasadniczej, «Rzeczpospolita» z 26 lipca $2010 \mathrm{r}$.

${ }^{6}$ Por. D. Dudek, op. cit. 
wykonywania kompetencji prezydenta, które nie maja postaci ściśle badź , względnie” określonych o b o wi a z kó w prawnych.

O tym, że takie wąskie rozumienie kompetencji osoby zastępującej Prezydenta jest właściwie, świadczy nie tylko konsekwentne posługiwanie się przez ustawodawcę konstytucyjnego w art. 131 pojęciem „obowiązków Prezydenta”, a nie „funkcji” lub „kompetencji”, lecz także art. 144, wymieniający prerogatywy, czyli tzw. kompetencje własne Prezydenta. Otóż art. 144 wprost mówi o katalogu „konstytucyjnych i ustawowych k o m p e t e n c j i ”, nie zaś „obowiązków”. Określenie „kompetencje” pojawia się też w art. 134 ust. 6 (,k o m p e t e n c j e Prezydenta związane ze zwierzchnictwem nad siłami zbrojnymi") $i$ art. 142 ust. 2 („Prezydent wydaje postanowienia w zakresie realizacji pozostałych swoich k o m pe t e n c j i ").

A zatem „obowiązkiem” będzie z pewnością podpisanie ustawy przekazanej przez Sejm, na co Prezydent ma 21 dni, zgodnie z art. 122 ust. 2 Konstytucji. Z pewnością obowiązkiem osoby tymczasowo zastępującej Prezydenta byłoby zarządzenie mobilizacji, zgodnie z art. 136, w razie bezpośredniego, zewnętrznego zagrożenia państwa.

Ale za „obowiązek” nie może być uznane wnoszenie projektów ustaw do Sejmu, co w normalnych okolicznościach przysługiwałoby Prezydentowi, podobnie zwracanie się z orędziem, nadawanie orderów i odznaczeń, powoływanie sędziów i wreszcie dokonywanie aktów nominacji, np. wnioskowanie o powołanie Prezesa NBP. Dlaczego nie można tu mówić o obowiązkach? Gdyż Prezydent nie jest we wskazanych wypadkach zobligowany do podejmowania działania w określonym terminie. Skoro tak, to z uwagi na wprost wskazany w Konstytucji tymczasowy charakter wykonywania obowiązków Prezydenta przez Marszałka Sejmu, winien on wstrzymać się z wszelką aktywnością, nie mającą $\mathrm{n}$ i e $\mathrm{z}$ b ę d n e g o charakteru.

Należy zauważyć, że w omawianym zakresie Konstytucja Kwietniowa mówiła w art. 23 o, ,wykonywaniu f u n k c j i " przez Marszałka Senatu. Co więcej, wprost podkreślała, że „Marszałek Senatu korzysta wówczas (w czasie opróżnienia urzędu) ze wszystkich u p r a w n i e ń z urzędem Prezydenta związanych". Podobnie Mała Konstytucja z 92 roku mówiła o „zastępowaniu Prezydenta przez Marszałka Sejmu”, 
identycznie jak Konstytucja Marcowa. Odejście od zasady, że Marszałek Sejmu lub Senatu całościowo „zastępuje Prezydenta”, bez rozróżniania kompetencji i obowiązków, na rzecz przyjętej w obecnej Konstytucji koncepcji wykonywania „obowiązków” musi być uznane za świadomą decyzję obecnego ustawodawcy konstytucyjnego, aby podkreślić tymczasowy charakter stanu opróżnienia urzędu Prezydenta.

Co do granic czasowych, w których możliwe jest wykonywanie obowiązków Prezydenta przez Marszałka Sejmu w razie opróżnienia urzędu Prezydenta, obecna Konstytucja wskazuje w art. 131 ust.2, że „Marszałek Sejmu tymczasowo, do c z a s u w y b o r u nowego Prezydenta, wykonuje obowiązki Prezydenta". Konstytucja nie definiuje pojęcia „czas wyboru”, niewątpliwie jednak „czas wyboru” nie jest tożsamy z pojęciem „objęcie urzędu”, gdyż jako jedną z przyczyn opróżnienia urzędu Prezydenta Konstytucja wskazuje w art. 131 ust. 2 pkt 3 ,inne przyczyny nieobjęcia urzędu po wyborze”. Objęcie urzędu, zgodnie $\mathrm{z}$ art. 130, następuje po złożeniu przysięgi wobec Zgromadzenia Narodowego. Oznacza to, że „wybór” i „objęcie urzędu" są dwoma różnymi zdarzeniami, a ustawodawca konstytucyjny zobowiązał Marszałka Sejmu do wykonywania obowiązków Prezydenta j e d y n i e do czasu wyboru.

Powyższe oznacza, że obecna Konstytucja przyjęła całkowicie odmienne rozwiązanie, niż poprzednie ustawy konstytucyjne. Mała Konstytucja z 1992 mówiła o zastępowaniu Prezydenta do „chwili objęcia urzędu przez nowego Prezydenta". Identyczne rozwiązanie, jak Mała Konstytucja, przyjmowała Nowela Kwietniowa z 1989 roku. Także przedwojenne konstytucje nie wprowadzały takiego pojęcia, jak „zastępowanie Prezydenta do czasu wyboru”.

Oczywiście jako kontrargument przeciwko takiemu sposobowi interpretacji można wskazać, że racjonalny ustawodawca nie dopuściłby do sytuacji, w której między chwilą wyboru, tj. ogłoszeniem wyników wyborów przez Państwową Komisję Wyborczą, a chwilą zaprzysiężenia, tj. przez ok 30 dni, nie zachowana byłaby ciagłość urzędu Prezydenta. Jednak lektura przepisów, w mojej ocenie, nie pozostawia wątpliwości, że intencją ustawodawcy było rozróżnienie momentu „wyboru” i „objęcia urzędu”. Skoro tak i skoro wskazano, że Marszałek 
Sejmu wykonuje obowiązki Prezydenta „do czasu wyboru”, to po ogłoszeniu wyników wyborów Marszałek Sejmu nie może zastępować Prezydenta. Podobnie uznali posłowie Platformy Obywatelskiej, wnosząc do Sejmu w lutym 2010, a więc jeszcze przed katastrofą smoleńską, projekt nowelizacji art. 131 Konstytucji, polegający na zastąpieniu słów „do czasu wyboru”, słowami „do czasu objęcia urzędu”, gdyż, jak napisali w uzasadnieniu, ,zgodnie z aktualnym stanem prawnym, w czasie opróżnienia urzędu Prezydenta, nie byłoby urzędującej głowy państwa" 7 .

W praktyce, po śmierci Prezydenta Lecha Kaczyńskiego w dniu 10 kwietnia 2010, obowiązki Prezydenta wykonywał Marszałek Sejmu, przy czym nie ograniczył się do wykonywania jedynie niezbędnych obowiązków, lecz wykonywał wszystkie kompetencje Prezydenta, łącznie ze wskazaniem kandydata na Prezesa Narodowego Banku Polskiego, zwoływaniem Rady Gabinetowej itp. Już po wyborze ówczesnego Marszałka Sejmu na Prezydenta i ogłoszeniu uchwały Państwowej Komisji Wyborczej z 5 lipca 2010 o tym, kto został Prezydentem, nadal Bronisław Komorowski wykonywał kompetencje Prezydenta (m.in. 7 lipca 2010 powołał nowych członków Krajowej Rady Radiofonii i Telewizji) i dopiero 8 lipca 2010 obowiązki Prezydenta zaczął wykonywać nowy Marszałek Sejmu Grzegorz Schetyna i wykonywał je do 6 sierpnia 2010 (w tym czasie m.in. wręczał odznaczenia, nadawał obywatelstwo polskie, wręczał nominacje sędziowskie, podejmował decyzje personalne ${ }^{8}$ ), tj. do dnia objęcia urzędu przez Prezydenta Bronisława Komorowskiego.

\section{Podsumowanie}

Prześledzenie rozwiązań konstytucyjnych w zakresie skutków opróżnienia urzędu pozwala dostrzec który organ w danej konstytucji miał szczególnie silną pozycję ustrojową. W Konstytucji Marcowej był to

${ }^{7}$ Druk sejmowy nr 2989 z 19 lutego 2010 oraz dostępne na stronie internetowej Sejmu RP ekspertyzy i opinie Biura Analiz Sejmowych.

${ }^{8}$ Informacje za oficjalną stroną Prezydenta Rzeczypospolitej: www.prezydent.pl (wg stanu na dzień 23 grudnia 2010). 
niewatpliwie Sejm, w kwietniowej - sam Prezydent, ograniczono bowiem katalog sytuacji, w których uznawano urząd Prezydenta za opróżniony, a nadto Senat. W III Rzeczpospolitej ponownie Marszałek Sejmu uzyskał w tym zakresie kompetencje do zastępowania Prezydenta. Obecnie obowiązujące przepisy, mimo że najbardziej rozbudowane ze wszystkich cytowanych rozwiązań, pozostawiają wiele do życzenia co do precyzji a nadto spójności systemowej - widać to na przykładzie naruszenia zasady ciągłości władzy państwowej przez brak przepisów o tym, kto ma wykonywać obowiązki Prezydenta po wyborze, a przed objęciem urzędu przez nowo wybranego Prezydenta.

The Consequences of a Vacancy in the Office of the President under $20^{\text {th }}$ Century Polish Constitutions

\section{Summary}

The article discusses the consequences of a vacancy in the office of the President of the Republic in $20^{\text {th }}$-century Polish constitutions. A vacancy in the office of the President takes place in the event of death, resignation, the election of a President being found invalid, among other possibilities.

The problem of succession to the office of President became particularly significant in connection with the Smolensk air disaster of 10 April 2010, which took the life of President Lech Kaczyński. This is why particular attention was paid to the provisions of the current Constitution adopted in 1997, pursuant to which the Speaker of the Sejm (lower house of Parliament) served as interim President. The article evaluates these provisions and their application from April to August 2010, i.e. until the swearing-in of the newly-elected President. 